\title{
Butterflies and Continuous Conservation Reserve Program Filter Strips: Landscape Considerations
}

\author{
Authors: Nicole M. Davros, Diane M. Debinski, \\ Kathleen F. Reeder, and William L. Hohman
}

This is the peer reviewed version of the following article: see , which has been published in final form in Wildlife Society Bulletin, available here.

Nicole M. Davros, Diane M. Debinski, Kathleen F. Reeder, and William L. Hohman. "Butterflies and Continuous Conservation Reserve Program Filter Strips: Landscape Considerations" Wildlife Society Bulletin Vol. 34 Iss. 4 (2006) p. 936 - 943. doi: 10.2193/0091-7648\%282006\%2934\% 5B936\%3ABACCRP\%5D2.0.CO\%3B2. 


\title{
Butterflies and Continuous Conservation Reserve Program Filter Strips: Landscape Considerations
}

\author{
NICOLE M. DAVROS, ${ }^{1}$ Department of Natural Resource Ecology \& Management, lowa State University, Ames, IA 50011, USA \\ DIANE M. DEBINSKI, ${ }^{2}$ Department of Ecology, Evolution, and Organismal Biology, lowa State University, Ames, IA 50011, USA \\ KATHLEEN F. REEDER, Department of Ecology, Evolution, and Organismal Biology, lowa State University, Ames, IA 50011, USA \\ WILLIAM L. HOHMAN, United States Department of Agriculture/Natural Resource Conservation Service, Central National Technology \\ Support Center, CNTSC, Fort Worth, TX 76115, USA
}

\begin{abstract}
Filter strips or buffers are areas of grass or other perennial herbaceous vegetation established along waterways to remove contaminants and sediments from agricultural field runoff. In the heavily cultivated regions of the Midwestern United States, these buffer zones established under the Farm Bill provide important habitat for wildlife such as butterflies. The question of how the landscape context of these plantings influences their use has not been adequately researched. We used multiple regression and Akaike's Information Criteria to determine how habitat width and several landscape-level factors (i.e., landscape composition [total herbaceous cover, amount of developed area, and amount of wooded cover] and configuration [herbaceous edge density]) influenced the abundance and diversity of the butterfly community using filter strips in southwestern Minnesota, USA. Habitatsensitive butterfly abundance and all richness and diversity measures were positively correlated with filter-strip width. Butterfly abundance was negatively associated with the amount of developed areas (cities, towns, and roads) within the area of a 1-km radius $\left(3.14 \mathrm{~km}^{2}\right)$ surrounding the sites. Percentage of wooded cover in the landscape was an important variable explaining individual species abundance, although the direction of the relationship varied. Our finding that landscape context influences butterfly use of filter strips highlights the importance of landscape-level approaches to wildlife conservation in agroecosystems. (WILDLIFE SOCIETY BULLETIN 34(4):936-943; 2006)
\end{abstract}

In the past 150 years, the Midwestern United States has undergone a dramatic conversion from tallgrass prairie to row-crop agriculture (Samson and Knopf 1994). Intensified land use has caused increased soil erosion and loss of wildlife habitat. The Conservation Reserve Program (CRP), authorized by the 1985 Farm Bill, has facilitated the reestablishment of natural vegetation, including grassland in the Midwest, by reimbursing farmers for taking land out of production and planting perennial vegetation in place of crops. The 1996 Farm Bill authorized a corollary to this program, the Continuous Conservation Reserve Program (CCRP), so-called because it allows producers to enroll on a continuous basis, instead of during a competitive sign-up period like the CRP. The CCRP targets highly erodible areas that are generally small in acreage and mostly linear in configuration. Examples of practices eligible for reimbursement under CCRP include riparian forest buffers, filter strips, grassed waterways, shelterbelts, and wetland buffers. This study focuses on filter strips, which comprise the largest proportion of the acreage enrolled under the CCRP, accounting for about 36\% of total CCRP acreage (Farm Service Agency [FSA] 2005). In particular, filter strips are areas of grass or other perennial herbaceous vegetation established along waterways to remove contaminants and sediments from agricultural field runoff (Schmitt et al. 1999,
Natural Resource Conservation Service [NRCS] 2003). An additional purpose of filter strips is to "restore, create, or enhance herbaceous habitat for wildlife and beneficial insects" (NRCS 2003:393-1).

This paper addresses a functional gap in research on the effects of American farm conservation programs on wildlife. Although the response of vertebrate organisms to CRP has been relatively well studied, especially for birds (Johnson and Schwartz 1993, Best et al. 1997, Delisle and Savidge 1997, Knoot 2004, Davros 2005, Henningsen and Best 2005), mammals (Chapman and Ribic 2002), and herpetofauna (Semlitsch and Bodie 2003, Knoot 2004), there is a significant gap in research relative to insect responses to farm conservation programs, especially from the perspective of landscape-level effects (Clark and Reeder 2005, Farrand and Ryan 2005).

Investigators who have studied insect use of farm-program plantings in the United States have focused primarily on local-level effects. Reeder et al. (2005) examined the influence of local habitat factors on butterfly use of filter strips, while Benson (2003) examined the effects of burning and disking on insect diversity in Wetlands Reserve Program floodplain easements in east-central Iowa, USA. Davros (2005) studied a wider array of insect taxa in Minnesota, USA, filter strips than Reeder et al., but again only included a local-level analysis. Insect community studies that have included landscape-level analyses have focused primarily on remnant grasslands rather than conservation buffers (Sutcliffe et al. 2002, Tscharntke et 
al. 2002, Weibull and Ostman 2003, Bergmann et al. 2004, Skibbe 2005).

In Midwestern row-crop agriculture settings where there is little remaining remnant grassland habitat, filter strips are important components of the contemporary landscape that have the potential to provide habitat for grasslanddependent wildlife (U.S. Department of Agriculture [USDA] 1997). We previously documented the influence of local habitat features on butterfly use of filter strips; for a detailed discussion of the importance of local effects, including vegetative composition and nectar availability, see Reeder et al. (2005). The best models to explain overall butterfly abundance included the percent cover of forbs and the number of flowering stems within the buffer strips. The models that best explained abundances of large, habitatsensitive butterflies such as Cercyonis pegala and Speyeria idalia included the height and vertical density of vegetation. However, given the effects of landscape on insect communities quantified in other systems described above, we wanted to also examine the potential of filter strips as butterfly habitat from a landscape perspective.

Butterflies are a valuable group to use as indicators of the effects of agroecological management on insect pollinators because they are diverse; approximately 50 butterfly species can occur in these habitats. They also are easier to identify compared with other insect groups that require additional hours of identification in the lab. Understanding how landscape context influences insects in filter strips is critical to a broader comprehension of the effects of farm conservation programs on important wildlife. The information gathered in this study may be used to help guide planning and implementation of USDA conservation buffers to optimize wildlife conservation benefits.

Our objectives were to quantify the habitat components of the landscape surrounding the filter strips within an area of $1-\mathrm{km}$ radius $\left(3.14 \mathrm{~km}^{2}\right)$ and to identify the habitat components most strongly correlated with butterfly distribution patterns. We included filter-strip width as a locallevel variable to compare its importance relative to landscape-level variables. We used width as our local metric because width rather than area may be the limiting factor for wildlife in these habitats; strip-cover habitats may be many miles long but can vary substantially in width along their course (Best 2000). We analyzed butterfly responses from the community perspective (abundance, richness, diversity) as well as from an individual species perspective when sample size permitted. We also examined responses by dividing the butterfly community into 2 guilds: disturbancetolerant species and habitat-sensitive species. We predicted that the amount of herbaceous cover and the amount of developed areas in the landscape would be important variables explaining diversity and abundance of butterflies using filter strips. We expected disturbance-tolerant species to be positively associated with landscapes that had a higher level of fragmentation, whereas habitat-sensitive species would be negatively associated with fragmentation in the landscape. We also predicted that filter-strip width would have a positive impact on the abundance of habitat-sensitive butterflies and on the diversity of the butterfly community in our sites.

\section{Study Area}

At the time of the study, Minnesota had $\sim 62,322$ ha (154,000 acres) of filter strips (Farm Service Agency 2005). Our research focused on filter strips in a 5-county area in southwest Minnesota (Jackson, Cottonwood, Watonwan, Nobles, and Brown counties), which covered portions of the Minnesota River and Des Moines River watersheds. Land in the area was primarily privately owned and was dominated by corn and soybean production.

\section{Study-Site Selection}

We chose 38 sites from a pool of potential filter strips in this 5-county area based upon the following 4 criteria: 1) filter strips were $\geq 3$ years old to allow for establishment of vegetation, 2) sites had $<15 \%$ trees or shrubs along the waterway, 3) filter strips were $\geq 350 \mathrm{~m}$ in length, and 4) sites were $\geq 1 \mathrm{~km}$ apart. Selected sites included filter strips buffering one or both sides of a waterway. All sites were bordered laterally by crops such as corn, soybeans, or wheat except for one site which was bordered by a gravel road. Our sites spanned a range of widths allowed under both CCRP (8-36 m) and Minnesota's Conservation Reserve Enhancement Program (36-148 m), a program that provides incentives for the widening of filter strips. Based on seeding plans filed with the NRCS, we initially categorized our sites as dominated by non-native plant species $(n=14)$, dominated by native plant species $(n=11)$, or switchgrass-dominated (Panicum virgatum; $n=13$ ). Smooth brome (Bromus inermis), reed canarygrass (Phalaris arundinacea), and quackgrass (Agropyron repens) were common in non-native filter-strip sites. Among native sites Canada wild rye (Elymus canadensis), Indiangrass (Sorghastrum nutans), and big and little bluestem (Andropogon spp.) were the most common species observed. Common forbs observed in all filter strips included Canada thistle (Cirsium canadense), alfalfa (Medicago sativa), and sweet clover (Melilotus spp.). Though each landowner individually managed filter strips, sites used in this study did not differ significantly in their management. None were treated with insecticide or fertilized; usual techniques for weed control were infrequent spot mowing and spot spraying.

\section{Methods}

\section{Transect Establishment and Study-Site Dimensions}

Each site had one survey transect. Each transect, marked with pin flags, was $200 \mathrm{~m}$ long $\times 5 \mathrm{~m}$ wide. We placed transects halfway between the waterway and the agricultural field, and they began at least $50 \mathrm{~m}$ from any roadway adjacent to the strip. We computed filter-strip width by averaging width measurements taken at 5 equidistant points along the length of each transect and one additional point $25-50 \mathrm{~m}$ beyond each end of the transect. 


\section{Landscape Characteristics}

We downloaded 2003 color aerial photos (2-m resolution) for each county from Minnesota's Land Management Information Center (LMIC) website (see acknowledgments for website information). Using ArcView Global Information System 3.3 (Environmental Systems Research Institute, Redlands, California) we hand-digitized each map feature within an area of $1-\mathrm{km}$ radius $\left(3.14 \mathrm{~km}^{2}\right)$ of the midpoint of each site transect. We then classified each feature to a habitat category, and later ground-truthed a subset of polygons for accuracy. Classifications used were as follows: 1) herbaceous habitat: state- or federally owned wildlife management areas, pastures, hayfields, CRP fields, smallgrain fields (e.g., wheat, rye), and herbaceous strip cover (roadsides, grassed waterways, filter strips, semi-permanent streams with herbaceous cover, terraces, fencerows); 2) row crop: corn or soybean fields; 3) wooded: woodlands, wooded stream corridors, woodlots, wooded roadsides, wooded fencerows; 4) wetlands and open water: wetlands, lakes, and large, fast-flowing rivers; and 5) developed areas: towns, cities, and all roads. We calculated percent landscape composition of each category for each site. We used the Patch Analyst extension in ArcView to quantify total edge density and herbaceous edge density ( $m$ of perimeter/ha of habitat category) to help describe the level of fragmentation in our landscapes (Fletcher and Koford 2002).

\section{Butterfly Abundance, Richness, and Diversity}

We conducted 2 butterfly surveys in 2002 (5-22 Jul and 22 Jul-15 Aug) and in 2003 (16 Jun-12 Jul and 15 Jul-11 Aug). Surveys coincided with periods of greatest butterfly activity; we conducted them on warm $\left(\geq 18^{\circ} \mathrm{C}\right)$, sunny $(<60 \%$ cloud cover), and calm (sustained winds $<16 \mathrm{~km} / \mathrm{hr}$ ) days between 0900-1730 hours. We modified butterfly-survey methods after Thomas (1983). Observers walked transects at a speed of $10 \mathrm{~m} /$ minute; survey effort was constant at 20 minutes/ transect. We identified all butterflies within a $5 \times 5-\mathrm{m}$ visual field in front of the observer and recorded their behavior. We stopped timers for capture and recording. We captured any butterflies that observers were unable to identify in the field using a net and transported them to the lab in a glassine envelope for identification. To minimize observer bias, we rotated surveyors at each site throughout the season.

\section{Statistical Analyses}

Prior to analysis, variables were natural-log or square-root transformed as necessary to improve normality and homogeneity of variances.

Landscape characteristics.-We computed means and standard errors for each landscape metric. The wetlandsopen water variable had a highly skewed distribution that could not be transformed to meet model assumptions, so the variable was dropped from subsequent analyses. Percent row-crop cover was highly correlated with total herbaceous cover, and total edge density was highly correlated with herbaceous edge density. We dropped both percent rowcrop cover and total edge density from further analyses to reduce problems of multicollinearity (Quinn and Keough
Table 1. Numbers of individuals of each butterfly species observed during transect surveys of 38 filter strips during the summers of 2002 and 2003 in southwestern Minnesota, USA. Butterflies were categorized into guilds using information on habitat, foodplants, and hostplants from Opler and Krizek (1984), Scott (1986), Glassberg (1999), and Ries et al. (2001). Butterflies occurring commonly in anthropogenically disturbed areas are classified as disturbance-tolerant (DT); species requiring unaltered habitat during any part of their life cycle are classified as habitat-sensitive (HS).

\begin{tabular}{|c|c|c|}
\hline Species & $\begin{array}{c}\text { No. of } \\
\text { individuals }\end{array}$ & $\begin{array}{l}\text { Guild } \\
\text { category }\end{array}$ \\
\hline Everes comyntas (Eastern tailed-blue) & 360 & DT \\
\hline Danaus plexippus (Monarch) & 234 & DT \\
\hline $\begin{array}{l}\text { Colias eurytheme/philodice } \\
\text { (Orange/Clouded sulphurs) }^{\text {a }}\end{array}$ & 170 & DT \\
\hline Ancyloxypha numitor (Least skipper) & 73 & DT \\
\hline Speyeria idalia (Regal fritillary) & 68 & HS \\
\hline Vanessa cardui (Painted lady) & 53 & DT \\
\hline $\begin{array}{l}\text { Cercyonis pegala (Common } \\
\text { wood-nymph) }\end{array}$ & 51 & HS \\
\hline Vanessa atalanta (Red admiral) & 42 & DT \\
\hline Pieris rapae (Cabbage white) & 14 & DT \\
\hline Satyrodes eurydice (Eyed brown) & 14 & HS \\
\hline Anatrytone logan (Delaware skipper) & 9 & HS \\
\hline Pholisora catullus (Common Sootywing) & 8 & DT \\
\hline Papilio polyxenes (Black swallowtail) & 6 & DT \\
\hline Speyeria cybele (Great spangled fritillary) & 5 & HS \\
\hline Papilio glaucus (Eastern tiger swallowtail) & 3 & $n / a^{b}$ \\
\hline $\begin{array}{l}\text { Pyrgus communis (Common } \\
\text { checkered-skipper) }\end{array}$ & 3 & HS \\
\hline Limenitis archippus (Viceroy) & 2 & DT \\
\hline Lycaena hyllus (Bronze copper) & 2 & HS \\
\hline Polites peckius (Peck's skipper) & 2 & DT \\
\hline $\begin{array}{l}\text { Polites themistocles (Tawny-edged } \\
\text { skipper) }\end{array}$ & 2 & DT \\
\hline Celastrina argiolus (Spring azure) & 1 & HS \\
\hline $\begin{array}{l}\text { Limenitis arthemis asyntax (Red-spotted } \\
\text { purple) }\end{array}$ & 1 & DT \\
\hline Phyciodes tharos (Pearl crescent) & 1 & DT \\
\hline Polites mystic (Long dash) & 1 & $\mathrm{HS}$ \\
\hline Polites origines (Crossline skipper) & 1 & HS \\
\hline Speyeria aphrodite (Aphrodite fritillary) & 1 & HS \\
\hline 27 Total Species & $1,127^{\mathrm{C}}$ & \\
\hline
\end{tabular}

${ }^{a}$ Colias spp. were combined due to initial identification uncertainty.

${ }^{b}$ Species adapted to woody habitats were not classified as disturbance-tolerant or habitat-sensitive.

${ }^{\mathrm{c}}$ Does not include individuals not identified to species.

2002:127). We used all remaining variables in the modelselection procedures described below.

Butterfly abundance, richness, and diversity.-To better understand the relationship between filter strips and the butterfly community, we separated the butterfly species into 2 guilds before conducting the analyses: disturbancetolerant and habitat-sensitive (Table 1). We categorized each species based upon information presented in Opler and Krizek (1984), Scott (1986), Glassberg (1999), Ries et al. (2001), and Reeder et al. (2005). Disturbance-tolerant butterflies are species that commonly can be found in areas altered by humans such as suburban lawns and gardens. Thus, they are effectively tolerant of removal of the native vegetation. Habitat-sensitive species have more specific requirements for habitat and vegetation composition and structure, either due to larval hostplant requirements or the 
needs of other life stages and are often found only in relatively natural areas (i.e., areas with native vegetation). We calculated butterfly abundance and Shannon-Weiner diversity $\left(\mathrm{H}^{\prime}\right)$ as means of all rounds, while we tallied species richness across rounds to arrive at a total number of species observed at each site over both years. We also used the abundances of species with a sufficient sample size $(>50$ observations) as a response variable in the analyses.

We analyzed the abundance, richness, and diversity of butterflies with respect to filter-strip width, percent cover of various elements of the landscape (herbaceous habitat, wooded land, and developed areas), and herbaceous edge density within the landscape. We used model-selection procedures to evaluate the variables important in determining butterfly community responses. We ran all combinations of variables (not including interactions) using multiple linear regression, then evaluated each model using Akaike's Information Criterion adjusted for small sample sizes $\left(\mathrm{AIC}_{c}\right)$ following Burnham and Anderson (2002). We considered models to be competing if they were within a $\Delta \mathrm{AIC}_{c}$ (i.e., $\mathrm{AIC}_{c i}-\operatorname{minAIC}{ }_{c}$ ) of 2 . We assessed modelselection uncertainty by evaluating $\Delta \mathrm{AIC}_{c}$ values, Akaike weights $\left(w_{\mathrm{i}}\right)$, and model-averaged parameter estimates (Burnham and Anderson 2002). We considered variables with a model-averaged parameter estimate of $> \pm 0.10$ to be important.

\section{Results}

\section{Landscape Characteristics}

Row crops dominated our landscapes, covering an average of $85 \%$ of the landscape (range $=68-94 \%$ ) within the 3.14$\mathrm{km}^{2}$ area around our sites. Herbaceous cover was the nexthighest cover type, covering $9 \%$ of the landscape (range $=4$ $25 \%$ ). Developed areas made up $1 \%$ (range $=0-15 \%$ ), wooded areas $0.7 \%$ (range $=0-4 \%$ ), and open waterwetlands $0.1 \%$ (range $=0-12 \%$ ) of the landscape. Average herbaceous edge density was $64 \mathrm{~m} / \mathrm{ha}$ (range $=40-105 \mathrm{~m} /$ ha).

\section{Butterfly Abundance, Richness, and Diversity}

We observed 1,227 individuals of 27 butterfly species (Table 1). Our models explained some variation $\left(R^{2}\right.$ range: $-0.02-$ 0.21 ) in butterfly abundance, richness, and diversity, although models for some measures were weak (Table 2). Butterfly use of filter strips was influenced by both local- and landscape-level variables. At the local level, all response variables were positively influenced by filter-strip width (Table 3). Habitat-sensitive butterflies, all richness measures, and Shannon-Weiner diversity strongly increased with filter-strip width. Individual species that responded strongly and positively to filter-strip width were Cercyonis pegala (common wood-nymph) and Vanessa cardui (painted lady). The most important landscape-level variables were the percent cover of developed and wooded areas within the area of a $1-\mathrm{km}$ radius $\left(3.14 \mathrm{~km}^{2}\right)$ surrounding our sites (Tables 2 and 3). Abundance and richness of all species and habitatsensitive species, Shannon-Weiner index of diversity, and abundance of Speyeria idalia (regal fritillary) decreased with the percent cover of developed areas. Abundance of Colias spp. (orange or clouded sulphurs), Danaus plexippus (monarch), and $S$. idalia increased with the amount of wooded cover in the landscape, while abundance of Ancyloxypha numitor (least skipper) was negatively associated with wooded cover. Overall, most variables showed a positive association with the amount of wooded cover. Abundance of Everes comyntas (eastern tailed-blue) was strongly and negatively associated with the amount of herbaceous cover in the landscape. Herbaceous edge density was negatively correlated with the abundance of $V$. cardui (Table 3).

\section{Discussion}

The importance of filter-strip width is reiterated in many of the models, and confirms the responses that we examined when describing the butterfly community at the local level (Reeder et al. 2005). Width was consistently positively associated with most of our butterfly response variables, signifying the potential conservation value of wider filter strips. In a companion study, Davros (2005) reported invertebrate taxa richness and abundance to be positively correlated with filter-strip width. Studies of other taxa (e.g., birds) have also reported positive relationships between abundance or richness and conservation-buffer width (Best 2000, Knoot 2004, Davros 2005, Henningsen and Best 2005). Filter-strip width also influences the total area of natural vegetation. To distinguish the effects of these 2 factors, we assessed the total herbaceous cover in the landscape within the 1-km-radius area (see below).

As observed in other landscape studies of butterflies in agroecosystems (e.g., Weibull and Ostman 2003, Bergmann et al. 2004, Skibbe 2005), we found that features in the surrounding landscape explained some of the variation in species distribution and abundance patterns. Although we did not examine landscape effects to the same spatial extent of Bergmann et al. (2004), we did find salient results, especially with respect to effects of width and percent cover of developed areas.

The predominance of the developed area variable in the models is striking. This variable appears in the best models for all abundance measures, total species richness, habitatsensitive species richness, Shannon-Weiner diversity of the entire community, and abundance of $S$. idalia. The consistently negative association between the amount of developed areas in the landscape and butterfly abundance, richness, and diversity suggests that these areas have negative impacts on butterfly occurrences. While our development variable is composed of cities, towns, and roads, it is primarily dominated by roads in the southern Minnesota landscape because relatively few of our sites are within $1 \mathrm{~km}$ of a town. The negative association between butterfly abundance and richness and percentage of developed areas may be due to mortality associated with roads. Southwestern Minnesota, like other areas of the Midwest, is composed of a grid of square-mile sections demarcated by roads. Ries et al. (2001) found that roadside 
Table 2. Best landscape models (i.e., models with $\Delta \mathrm{AlC}_{c}<2$ and highest $w_{\mathrm{i}}$ ) for butterfly abundance, richness, and diversity in 38 United States Department of Agriculture filter strips in southwestern Minnesota, USA, Jun-Aug 2002 and 2003. ${ }^{a}$

\begin{tabular}{|c|c|c|c|c|c|c|}
\hline Butterfly variable & $K^{b}$ & $\mathrm{AlC}_{c}$ & $\Delta \mathrm{AlC}_{c}$ & $w_{i}$ & Adj. $R^{2}$ & Variables $^{c}$ in model \\
\hline Abundance & & - & & & & \\
\hline \multirow{3}{*}{ All species } & 2 & -36.6 & 0.00 & 0.18 & 0.04 & -Develop \\
\hline & 3 & -34.82 & 1.78 & 0.07 & 0.03 & AveWidth - Develop \\
\hline & 2 & -34.81 & 1.79 & 0.07 & -0.01 & AveWidth \\
\hline \multirow[t]{5}{*}{ Disturbance-tolerant } & 2 & -30.79 & 0.00 & 0.13 & 0.02 & -Develop \\
\hline & 2 & -29.96 & 0.84 & 0.09 & 0.00 & $-\mathrm{HED}$ \\
\hline & 2 & -29.89 & 0.90 & 0.08 & 0.00 & AveWidth \\
\hline & 2 & -29.25 & 1.54 & 0.06 & 0.02 & Wooded \\
\hline & 3 & -29.25 & 1.54 & 0.06 & 0.02 & AveWidth - Develop \\
\hline \multirow[t]{8}{*}{ Habitat-sensitive } & 3 & 115.24 & 0.00 & 0.10 & 0.09 & AveWidth - Develop \\
\hline & 3 & 115.39 & 0.15 & 0.09 & 0.08 & TotHerb - Develop \\
\hline & 2 & 115.46 & 0.23 & 0.09 & 0.05 & AveWidth \\
\hline & 2 & 115.60 & 0.36 & 0.08 & 0.05 & -Develop \\
\hline & 2 & 116.10 & 0.86 & 0.06 & 0.03 & TotHerb \\
\hline & 3 & 116.33 & 1.10 & 0.06 & 0.06 & -Develop + HED \\
\hline & 4 & 116.51 & 1.27 & 0.05 & 0.09 & AveWidth - Develop + HED \\
\hline & 4 & 116.54 & 1.30 & 0.05 & 0.09 & AveWidth + TotHerb - Develop \\
\hline \multirow[t]{4}{*}{ Ancyloxypha numitor } & 2 & 132.69 & 0.00 & 0.16 & 0.02 & -Wooded \\
\hline & 2 & 134.03 & 1.34 & 0.08 & -0.01 & AveWidth \\
\hline & 3 & 134.28 & 1.59 & 0.07 & 0.02 & AveWidth - Wooded \\
\hline & 2 & 134.36 & 1.67 & 0.07 & -0.02 & -TotHerb \\
\hline \multirow[t]{2}{*}{ Colias spp. } & 2 & -14.54 & 0.00 & 0.25 & 0.14 & Wooded \\
\hline & 3 & -13.32 & 1.22 & 0.14 & 0.14 & Wooded + HED \\
\hline \multirow[t]{3}{*}{ Cercyonis pegala } & 2 & 129.20 & 0.00 & 0.16 & 0.08 & AveWidth \\
\hline & 3 & 130.37 & 1.16 & 0.09 & 0.08 & AveWidth - Wooded \\
\hline & 3 & 130.89 & 1.68 & 0.07 & 0.07 & AveWidth + TotHerb \\
\hline \multirow[t]{3}{*}{ Danaus plexippus } & 2 & 106.90 & 0.00 & 0.18 & 0.06 & Wooded \\
\hline & 3 & 108.49 & 1.59 & 0.08 & 0.05 & AveWidth + Wooded \\
\hline & 3 & 108.53 & 1.62 & 0.08 & 0.05 & TotHerb + Wooded \\
\hline \multirow[t]{2}{*}{ Everes comyntas } & 2 & 75.88 & 0.00 & 0.24 & 0.13 & -TotHerb \\
\hline & 3 & 76.84 & 0.96 & 0.15 & 0.14 & -TotHerb - Develop \\
\hline \multirow[t]{2}{*}{ Vanessa cardui } & 2 & 131.03 & 0.00 & 0.15 & 0.04 & AveWidth \\
\hline & 3 & 131.83 & 0.80 & 0.10 & 0.05 & AveWidth - HED \\
\hline \multirow[t]{3}{*}{ Speyeria idalia } & 2 & 128.81 & 0.00 & 0.15 & 0.06 & -Develop \\
\hline & 3 & 129.59 & 0.78 & 0.10 & 0.07 & -Develop + Wooded \\
\hline & 2 & 130.13 & 1.33 & 0.08 & 0.03 & Wooded \\
\hline \multicolumn{7}{|l|}{ Richness } \\
\hline \multirow[t]{2}{*}{ All species } & 3 & 61.95 & 0.00 & 0.19 & 0.15 & AveWidth - Develop \\
\hline & 2 & 62.27 & 0.32 & 0.16 & 0.11 & AveWidth \\
\hline \multirow[t]{3}{*}{ Disturbance-tolerant } & 2 & 36.82 & 0.00 & 0.13 & 0.03 & AveWidth \\
\hline & 2 & 37.17 & 0.35 & 0.11 & 0.02 & Wooded \\
\hline & 3 & 37.32 & 0.50 & 0.10 & 0.05 & AveWidth + Wooded \\
\hline Habitat-sensitive & 3 & 3.45 & 0.00 & 0.29 & 0.21 & AveWidth - Develop \\
\hline \multicolumn{7}{|l|}{ Diversity } \\
\hline \multirow{6}{*}{ Shannon-Weiner } & 3 & -131.27 & 0.00 & 0.12 & 0.12 & AveWidth - Develop \\
\hline & 2 & -130.58 & 0.68 & 0.09 & 0.07 & AveWidth \\
\hline & 2 & -130.03 & 1.24 & 0.07 & 0.06 & -Develop \\
\hline & 4 & -129.94 & 1.33 & 0.06 & 0.12 & AveWidth - Develop + Wooded \\
\hline & 3 & -129.82 & 1.44 & 0.06 & 0.09 & AveWidth + Wooded \\
\hline & 3 & -129.76 & 1.51 & 0.06 & 0.08 & TotHerb - Develop \\
\hline
\end{tabular}

${ }^{a}$ Abbreviations: $\mathrm{AlC}_{c}=$ Akaike's Information Criterion adjusted for small sample size; $w_{i}=$ Akaike weight; Adj. $=$ adjusted.

${ }^{\mathrm{b}} \mathrm{K}$ indicates the number of parameters used in the regression model $(+1)$.

${ }^{c}$ Explanatory variables: AveWidth $=$ average width of filter strip as determined by on-the-ground measurements; TotHerb $=$ total amount of herbaceous cover in landscape (\%); Develop = amount of all cities, towns, and roads in landscape (\%); Wooded = amount of wooded cover in landscape (\%); HED = total herbaceous edge density in landscape ( $\mathrm{m} / \mathrm{ha})$.

plantings in Iowa could attract butterflies, but that roads, especially paved roads, pose a significant mortality risk to butterflies. They estimated the mortality risk for a butterfly crossing a road to be $7 \%$ for paved roads and $1 \%$ for gravel roads (Ries et al. 2001). Many of the roads in our study area are gravel, and, because many butterfly species display mudpuddling behavior, they may experience increased mortality from congregating on the road. Skibbe (2005) also found $S$. idalia to be negatively associated with roads in Iowa.

Percent cover of wooded habitat in the landscape may be more representative of riparian or degraded woodland cover within the area of a $1-\mathrm{km}$ radius surrounding our sites. We specifically chose filter strips with few if any trees, so any wooded habitat components were not within the filter strips 
Table 3. Model-averaged parameter estimates for variables in regression models of butterfly abundance, species richness, and diversity in 38 United States Department of Agriculture filter strips in southwestern Minnesota, USA, Jun-Aug 2002 and 2003. The parameter estimates are weighted based on the sum of Akaike weights $\left(w_{i}\right)$ over candidate models in which the variable occurred. Numbers in bold are $> \pm 0.10$ and were considered important.

\begin{tabular}{|c|c|c|c|c|c|}
\hline \multirow[b]{2}{*}{ Butterfly variable } & \multirow[b]{2}{*}{ AveWidth $^{\mathrm{a}}$} & \multicolumn{4}{|c|}{ Landscape variables $^{\mathbf{b}}$} \\
\hline & & TotHerb & Develop & Wooded & HED \\
\hline \multicolumn{6}{|l|}{ Abundance } \\
\hline All species & 0.05 & 0.00 & -0.15 & 0.03 & 0.00 \\
\hline Disturbance-tolerant & 0.07 & -0.02 & -0.09 & 0.03 & -0.06 \\
\hline Habitat-sensitive & 0.12 & 0.09 & -0.18 & 0.01 & 0.04 \\
\hline Ancyloxypha numitor & 0.05 & 0.03 & -0.01 & -0.12 & 0.00 \\
\hline Colias spp. & 0.00 & -0.02 & -0.02 & 0.34 & 0.09 \\
\hline Cercyonis pegala & 0.20 & 0.08 & -0.05 & -0.08 & 0.01 \\
\hline Danaus plexippus & 0.04 & 0.05 & 0.03 & 0.19 & 0.00 \\
\hline Everes comyntas & 0.00 & -0.34 & -0.07 & -0.01 & -0.01 \\
\hline Vanessa cardui & 0.15 & 0.06 & 0.01 & 0.00 & -0.11 \\
\hline Speyeria idalia & 0.05 & 0.01 & -0.18 & 0.10 & 0.00 \\
\hline \multicolumn{6}{|l|}{ Richness } \\
\hline All species & 0.31 & -0.02 & -0.13 & 0.03 & -0.01 \\
\hline Disturbance-tolerant & 0.14 & -0.02 & -0.03 & 0.11 & -0.01 \\
\hline Habitat-sensitive & 0.32 & 0.00 & -0.25 & -0.01 & 0.01 \\
\hline \multicolumn{6}{|l|}{ Diversity } \\
\hline Shannon-Weiner & 0.17 & 0.06 & -0.18 & 0.06 & 0.02 \\
\hline
\end{tabular}

${ }^{a}$ Average width of filter strips as determined by on-the-ground measurements.

b Landscape variables: TotHerb = total amount of herbaceous cover in landscape (\%); Develop = amount of all cities, towns, and roads in landscape (\%); Wooded = amount of wooded cover in landscape (\%); HED = total herbaceous edge density in landscape (m/ha).

themselves. Strong relationships between disturbance-tolerant species and wooded habitats may result from availability of mud-puddling sites or tolerance of degraded habitats. Because Colias spp. make up a large percentage of the abundance of disturbance-tolerant species, this may explain the positive association between disturbance-tolerant species richness and wooded habitat. In addition, some butterfly species use trees as perching sites in the evenings. Danaus plexippus is a case in point, so it is not surprising that it responded positively to the percent wooded cover within the landscape we examined. Speyeria idalia may be using wooded riparian areas for mud-puddling. Ancyloxypha numitor responded negatively to wooded cover. It is a species that prefers open habitats and, thus, may be avoiding the shade that wooded areas provide.

Herbaceous edge density was used as a measure of habitat fragmentation. We expected that disturbance-tolerant species would be associated with high levels of herbaceous edge density. As expected, Colias spp. (both disturbancetolerant species) showed weak but positive associations with herbaceous edge density. Colias species are the epitome of butterfly edge species in Midwestern landscapes and often are found along roadside edges. Because clover (Trifolium repens) is a hostplant for both Colias species and is found along roadsides, it is not surprising that these Colias species showed positive associations with edge habitats in this landscape. However, disturbance-tolerant species as a group and $V$. cardui specifically showed negative associations with herbaceous edge density. Thus, even disturbance-tolerant species may prefer less-fragmented patches.

We expected that total herbaceous cover would be an important landscape component for the butterfly commu- nity, as was found by Skibbe (2005). Total herbaceous cover does show up as a positive influence in competing models for habitat-sensitive abundance and Shannon-Weiner diversity. However, the model-averaged parameter estimates for each are weaker, indicating that this variable is not as important as other landscape variables in explaining habitatsensitive abundance and overall diversity. Herbaceous cover also is weakly positively associated with individual species such as $D$. plexippus but strongly and negatively associated with $E$. comyntas. Everes comyntas is a small butterfly with rounded wings that uses the landscape on a very fine scale. As compared to $D$. plexippus, this less vagile species probably is much less affected by the larger landscape scale. These differing responses to landscape factors based upon species mobility are similar to the results found by Tscharntke et al. (2002).

Additional research is needed to clarify the relationships between wildlife communities in buffers and the amount of herbaceous cover in the surrounding landscape. Because our study area is heavily agricultural, herbaceous cover in our landscapes only ranged from $4-25 \%$ and was often linear in form. Only a small number of sites had $>15 \%$ herbaceous cover in the surrounding area described by the $1-\mathrm{km}$ radius. Butterfly responses to the amount of grassland habitat in the landscape may have been stronger if some of our sites had $>50 \%$ herbaceous cover. Such a response to the amount of perennial cover in the landscape has been modeled for other taxa. For example, Clark et al. (2001) demonstrated that predicted response of pheasant (Phasianus colchicus) abundance in Iowa landscapes would not reach peak abundance until nearly $50 \%$ of the landscape was in perennial grassland. Because it is difficult to find areas with perennial grassland 
covering such large portions of the landscape in our study region, comparable studies in other regions could provide important information about thresholds. Modeling approaches also could be undertaken to predict how many conservation program plantings would be necessary to create a persistent, positive change in wildlife population sizes in agricultural areas.

\section{Management Implications}

Filter strips are important tools for protecting water quality, but creation and maintenance of wildlife habitat also is an explicit goal of many buffer practices. Because buffer plantings provide a significant proportion of the habitat available to wildlife in heavily cultivated regions like the Midwest, it is crucial to understand how their utility to wildlife can be maximized. Based on our findings and on the results of our previous research on local variables, we recommend planting buffers to be as wide as possible, with diverse vegetative composition and structure to enhance wildlife benefits. The percent cover of forbs, number of forb stems in bloom, height, and vertical density of the vegetation all are important (Reeder et al. 2005). This vegetative diversity can provide both resources of nectar, and, if the plantings are especially diverse, may even provide host plants for the habitat-sensitive species.

Our finding that landscape variables such as percent wooded cover and percent developed areas help explain abundance, richness, and diversity of the butterfly community highlights the importance of broadening our understanding of how landscape variables affect wildlife in farmprogram plantings. In addition, the influence of landscape variables on wildlife in buffers has repeatedly been demonstrated (Clark et al. 2001, Knoot 2004, Davros 2005), but many farm-bill programs currently are not set up

\section{Literature Cited}

Benson, T. J. 2003. Breeding bird, plant, and arthropod responses to restoration and management of riparian conversation easements in the lowa River Corridor, east-central lowa. Thesis, lowa State University, Ames, USA.

Bergmann, K. O., J. Askling, O. Ekberg, H. Ignell, H. Wahlman, and P. Milberg. 2004. Landscape effects on butterfly assemblages in an agricultural region. Ecography 27:619-628.

Best, L. B. 2000. Continuous Enrollment Conservation Reserve Program: the value of buffer habitats for birds in agricultural landscapes. Pages 75-94 in W. L. Hohman and D. J. Halloum, editors. A comprehensive review of Farm Bill contributions to wildlife conservation, 1985-2000. U.S. Department of Agriculture, Natural Resource Conservation Service, Wildlife Habitat Management Institute, Technical Report, USDA/NRCS/WHMI-2000, Madison, Mississippi, USA.

Best, L. B., H. Campa, III, K. E. Kemp, R. J. Robel, M. R. Ryan, J. A. Savidge, H. P. Weeks, and S. R. Winterstein. 1997. Bird abundance and nesting in CRP fields and cropland in the Midwest: a regional approach. Wildlife Society Bulletin 25:864-877.

Burnham, K. P., and D. R. Anderson. 2002. Model selection and multimodel inference: a practical information-theoretic approach. Second edition. Springer-Verlag, New York, New York, USA.

Chapman, E. W., and C. A. Ribic. 2002. The impact of buffer strips and stream-side grazing on small mammals in southwestern Wisconsin. Agriculture, Ecosystems and Environment 88:49-59.

Clark, W. R., B. L. Falk, R. A. Schmitz, and B. A. Babcock. 2001. to allow the geographic targeting of specific areas based on landscape features. This is beginning to change as the importance of landscape and watershed approaches has become better understood; some Conservation Reserve Enhancement Programs now target specific areas and landowners for enrollment to allow planning on a regional scale. To the extent that targeting is practical and does not unduly hinder participation in farm bill programs, we recommend that programs used to achieve wildlife conservation goals incorporate such landscape-oriented approaches.

\section{Acknowledgments}

The USDA-NRCS-Wildlife Habitat Management Institute provided the primary funding for this project. We thank P. Flynn and M. Oja of the USDA-NRCS Minnesota State Office, and M. Apple and A. English of the USDA-NRCS Minnesota Area Offices. We also are thankful to the Minnesota NRCS county office staffs in Brown, Cottonwood, Jackson, Nobles, and Watonwan counties and the Cottonwood County Soil and Water District staff. C. Shumaker, T. Hanson (Department of Natural Resource Ecology and Management, Iowa State University), and K. Haroldson (Minnesota Department of Natural Resources) provided Geographic Information Systems help along the way. We thank S. Hacker and B. Arp for providing excellent field assistance, and T. Thompson and the Willow Lake Farm crew for providing hospitality during our summers in Minnesota. This research was made possible through the gracious cooperation of many local landowners and operators. Aerial photography for each county was obtained from Minnesota's LMIC at: <http://www.lmic.state.mn.us/ chouse/naip03mrsid.html $>$.

Projecting the wildlife and economic impacts of United States agricultural policy using landscape-level analyses. Pages 139-143 in R. Field, R. J. Warren, H. Okarma, and P. R. Sievert, editors. Wildlife, land and people: priorities for the 21st century. Proceedings of Second International Wildlife Management Congress. The Wildlife Society, Bethesda, Maryland, USA.

Clark, W. R., and K. F. Reeder. 2005. Continuous enrollment conservation reserve program: factors influencing the value of agricultural buffers to wildlife conservation. Pages 93-113 in J. Haufler, editor. Fish and wildlife benefits of Farm Bill Conservation Programs 2000-2005 update. U.S. Department of Agriculture, Natural Resource Conservation Service. <http://www.nrcs.usda. gov/technical/nri/ceap/fwbenefit.html>. Accessed 2006 Jan 18.

Davros, N. M. 2005. Grassland bird and arthropod responses to USDA filter-strip characteristics in southwestern Minnesota. Thesis, lowa State University, Ames, USA.

Delisle, J. M., and J. A. Savidge. 1997. Avian use and vegetation characteristics of Conservation Reserve Program fields. Journal of Wildlife Management 61:318-325.

Farm Service Agency. 2005. Conservation Reserve Program monthly summary-October 2005. <http://www.fsa.usda.gov/dafp/cepd/ stats/Oct2005.pdf >. Accessed 2005 Oct 20.

Farrand, D. T., and M. R. Ryan. 2005. Impact of the Conservation Reserve Program on wildlife conservation in the Midwest. Pages 4162 in J. Haufler, editor. Fish and wildlife benefits of Farm Bill Conservation Programs 2000-2005 update. U.S. Department of 
Agriculture, Natural Resource Conservation Service. <http://www. nrcs.usda.gov/technical/nri/ceap/fwbenefit.html>. Accessed 2006 Jan 18.

Fletcher, R. J., Jr., and R. R. Koford. 2002. Habitat and landscape associations of breeding birds in native and restored grasslands. Journal of Wildlife Management 66:1011-1022.

Glassberg, J. 1999. Butterflies through binoculars: the East. Oxford University, New York, New York, USA.

Henningsen, J. C., and L. B. Best. 2005. Grassland bird use of riparian filter strips in southeast lowa. Journal of Wildlife Management 69: 198-210.

Johnson, D. H., and M. D. Schwartz. 1993. The Conservation Reserve Program and grassland birds. Conservation Biology 7:934-937.

Knoot, T. G. 2004. The influence of local and landscape factors on wildlife use of grassed waterways in Southeast lowa. Thesis, lowa State University, Ames, USA.

Natural Resource Conservation Service. 2003. National handbook of conservation practices: conservation practice standard, filter strip. Natural Resource Conservation Service code 393, Washington, D.C., USA.

Opler, P. A., and G. O. Krizek. 1984. Butterflies east of the Great Plains. The Johns Hopkins University, Baltimore, Maryland, USA.

Quinn, G. P., and M. J. Keough. 2002. Experimental design and data analysis for biologists. Cambridge University, Cambridge, United Kingdom.

Reeder, K. F., D. M. Debinski, and B. J. Danielson. 2005. Factors affecting butterfly use of filter strips in Midwestern USA. Agriculture, Ecosystems and Environment 109:40-47.

Ries, L., D. M. Debinski, and M. L. Weiland. 2001. Conservation value of roadside prairie restoration to butterfly communities. Conservation Biology 15:401-411.

Samson, F., and F. Knopf. 1994. Prairie conservation in North America. BioScience 44:418-421.

Schmitt, T. J., M. G. Dosskey, and K. D. Hoagland. 1999. Filter-strip performance and processes for different vegetation, widths, and contaminants. Journal of Environmental Quality 28:1479-1489.

Scott, J. A. 1986. The butterflies of North America. Stanford University, Stanford, California, USA.

Semlitsch, R. D., and J. R. Bodie. 2003. Biological criteria for buffer zones around wetlands and riparian habitats for amphibians and reptiles. Conservation Biology 17:1219-1228.

Skibbe, J. D. 2005. Butterfly community composition in fragmented habitats: effects of patch shape and spatial scale. Thesis, lowa State University, Ames, USA.

Sutcliffe, O. L., V. Bakkestuen, G. Fry, and O. E. Stabbetorp. 2002. Modeling the benefits of farmland restoration: methodology and application to butterfly movement. Landscape and Urban Planning 63:15-31.

Thomas, J. A. 1983. A quick method for estimating butterfly numbers during surveys. Biological Conservation 27:195-211.

Tscharntke, T., I. Steffan-Dewenter, A. Kruess, and C. Thies. 2002. Contribution of small habitat fragments to conservation of insect communities of grassland-cropland landscapes. Ecological Applications 12:354-363.

United States Department of Agriculture. 1997. Buffers: commonsense conservation. Natural Resource Conservation Service, Pro- gram Aid-1615, Washington, D.C., USA. <http://www.nrcs.usda. gov/feature/buffers/>. Accessed $2006 \mathrm{Jul} 14$

Weibull, A. C., and O. Ostman. 2003. Species composition in agroecosystems: the effect of landscape, habitat, and farm management. Basic and Applied Ecology 4:349-361.

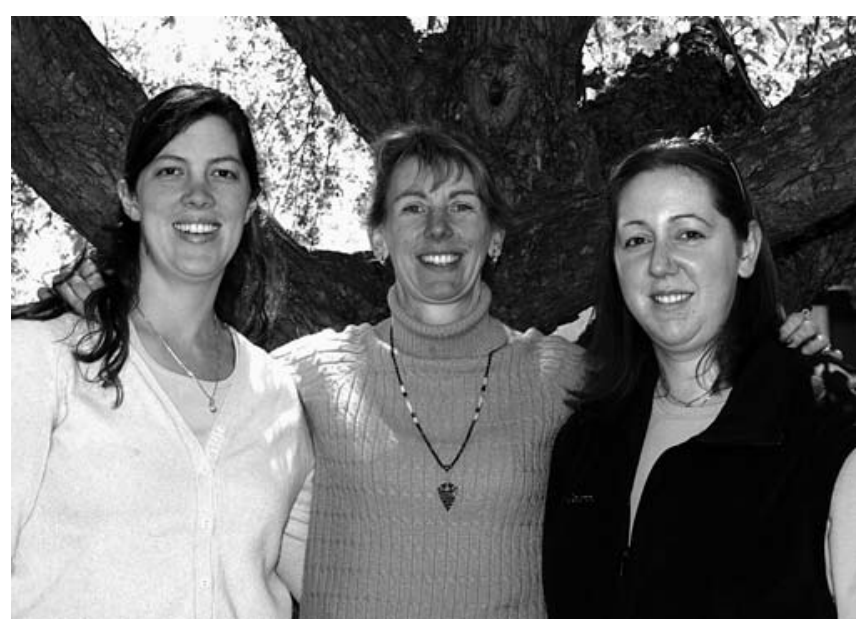

Nicole M. Davros (right) received her B.S. from the University of Illinois at Urbana-Champaign in 1999 and her M.S. from lowa State University in 2005. She will begin working on her Ph.D. at the University of Illinois at Urbana-Champaign in the autumn of 2006. Her primary interests are in avian ecology and conservation. In her free time, she enjoys spending time outdoors and with her family. Diane M. Debinski (middle) is an associate professor in the Department of Ecology, Evolution, and Organismal Biology at lowa State University. Her primary interests are in the areas of conservation biology, restoration ecology, and landscape ecology. Her field research focuses on prairie restoration, habitat fragmentation, and effects of global climate change. In her free time, she enjoys hiking and canoeing with her family. Kathleen F. (Katy) Reeder (left) received her B.S. from Earlham College and her M.S. from lowa State University in 2005. Her primary interests are in conservation biology and sustainable agriculture. In her free time she enjoys visiting with her family and spending time outside with her dogs. William L. (Bill) Hohman (not pictured) has been a wildlife biologist with the U.S. Department of Agriculture (USDA), Natural Resource Conservation Service and a collaborating assistant professor in the Natural Resource Ecology and Management Department at lowa State University since 1997. His primary interests are life-history strategies of birds, especially waterbirds, and assessment of wildlife responses to USDA conservation programs and practices.

Special Section Associate Editor: Teels. 